\title{
Oxytocin infusion during second stage of labour in primiparous women using epidural analgesia: a randomised double blind placebo controlled trial
}

\author{
Nigel J St G Saunders, Helen Spiby, Lucy Gilbert, Robert B Fraser, Jacqueline M Hall, \\ Philip M Mutton, Ann Jackson, Douglas K Edmonds
}

\section{Northern General \\ Hospital, Sheffield S5 7AU Nigel J St G Saunders, MRCOG, lecturer \\ Helen Spiby, SCM, midwifery sister \\ Lucy Gilbert, MRCOG, registrar \\ Robert B Fraser, FRCOG, senior lecturer}

\section{Queen Charlotte's} Maternity Hospital, London W6 0XG Jacqueline M Hall, MRCOG, registrar

Philip M Mutton, MRCOG, registrar

Ann Jackson, MB, senior house officer

Douglas K Edmonds, MRCOG, consultant obstetrician

Correspondence to: Mr N J Saunders, Department of Obstetrics and Gynaecology, St Mary's Hospital Medical School, London W2 1PG.

BrMed f 1989;299:1423-6

\begin{abstract}
Objective-To determine whether the high rate of forceps delivery associated with the use of epidural analgesia could be reduced through giving an intravenous infusion of oxytocin during the second stage
\end{abstract} of labour.

Design-A randomised, double blind, placebo controlled trial.

Setting-Delivery suites in three hospitals.

Subjects-226 Primiparous women with adequate epidural analgesia in whom full dilatation of the cervix had been achieved without prior stimulation with oxytocin.

Intervention-An infusion of oxytocin or placebo starting at the diagnosis of full cervical dilatation at an initial dose rate of $2 \mathrm{mU} / \mathrm{min}$ increasing to a maximum of $16 \mathrm{mU} / \mathrm{min}$.

Main outcome measures-The outcome of labour was assessed in terms of the duration of the second stage, mode of delivery, fetal condition at birth, postpartum blood loss, and the incidence of perineal trauma.

Results - Treatment with oxytocin was associated with a shorter second stage $(p=0.01)$, a reduction in the number of non-rotational forceps deliveries $(p=0.03)$, and less perineal trauma $(p=0.03)$ but was not associated with any reduction in the number of rotational forceps deliveries performed for malposition of the occiput. No adverse effects on fetal condition at birth or in the early puerperium were seen in association with the use of oxytocin.

Conclusions-The use of an oxytocin infusion may reduce the high rate of operative delivery associated with epidural analgesia provided that the fetal occiput is in an anterior position at the onset of the second stage of labour but within the dose range studied does not seem to correct malposition of the fetal occiput.

\section{Introduction}

Epidural analgesia has gained widespread acceptance in British obstetric practice in recent years and provides excellent pain relief for women in labour. This degree of analgesia, however, is obtained at a price - namely, an increased requirement for operative vaginal delivery often in association with malposition of the occiput. ${ }^{12}$ Attempts to improve the rate of spontaneous delivery by allowing the analgesia to wear off in the second stage of labour have not been successful, ${ }^{3}$ and furthermore this manoeuvre defeats the aim of good obstetric analgesia.

Allowing a longer second stage of labour in patients with epidurals in conjunction with delayed maternal pushing has been advocated, but the results from controlled studies have produced conflicting results. McQueen and Mylrea found less malrotation of the occiput with this approach but no overall reduction in the forceps rate. ${ }^{4}$ Maresh et al reported an improvement in the rate of spontaneous deliveries which was not significant ${ }^{5}$ whereas Buxton et al recorded a higher rate of operative delivery in association with delayed pushing. ${ }^{6}$

The role of endogenous oxytocin in the initiation and maintenance of normal labour has been difficult to define because of methodological problems associated with the measurement of plasma oxytocin. Some authors have reported a rise in maternal oxytocin concentrations coincident with descent of the vertex during the second stage of labour..$^{7-10}$ Certainly in animals the neurohumoral reflex first suggested by Ferguson does seem to exist ${ }^{11}$ whereby distension of the birth canal stimulates the release of oxytocin. ${ }^{12}$ If such a reflex also exists in humans it is reasonable to suppose that any increase in endogenous oxytocin concentrations would augment uterine activity at the most appropriate time-that is, during the second stage of labour as the fetus begins its descent through the pelvis. Epidural analgesia may possibly abolish this reflex by blocking conduction pathways in spinal autonomic nerve fibres. Goodfellow et al reported that maternal oxytocin concentrations during the second stage of labour were lower in patients using epidural analgesia than in controls, ${ }^{9}$ and as a corollary a reduction in integrated uterine activity has also been recorded. ${ }^{13}$

In view of the above evidence we studied the effect of oxytocin infusion given from the beginning of the second stage of labour to women receiving epidural analgesia to ascertain whether this might reduce the rate of operative vaginal delivery.

\section{Patients and methods}

This collaborative study was undertaken at the Northern General and Nether Edge Hospitals, Sheffield, and Queen Charlotte's Maternity Hospital, London, over three years (April 1986-9). In all three units the same agreed protocol was used from the outset.

Patients eligible for entry into the study were healthy primiparous women carrying a singleton fetus with a vertex presentation and an estimated gestational age of between 37 and 42 weeks. All women had to have entered the second stage of labour without prior oxytocin augmentation and have had an epidural sited and producing adequate analgesia. When possible the aims of the study were explained to patients in the antenatal clinic before labour, and provisional consent was obtained at this stage and confirmed when the 
patients were admitted in labour. In labour vaginal examinations were performed every four hours until the cervix was $7 \mathrm{~cm}$ dilated. After this point the frequency of subsequent examinations was as follows: at $7 \mathrm{~cm}$ the patient was examined after three hours, at $8 \mathrm{~cm}$ after two hours, and at $9 \mathrm{~cm}$ after one hour to ensure that the diagnosis of full dilatation was not unduly delayed. Epidural catheters were sited at the L3-4 joint space through a 16 gauge Tuohy needle. After a $2 \mathrm{ml}$ test dose of $0.375 \%$ bupivacaine subsequent volumes of $10 \mathrm{ml}$ of local anaesthetic were used.

At the diagnosis of full dilatation the patients were randomised into treatment and control groups. The study was double blind but whereas in Sheffield the infusions of oxytocin in physiological saline or physiological saline alone were prepared by the hospital pharmacy on the basis of random number allocation in London the randomisation was performed by using coded phials of oxytocin or placebo, which were added to the infusion by labour ward staff, the key to the coding system being held by the hospital pharmacy. This difference in randomisation procedures between Sheffield and London was due to local circumstances but in all other respects the two centres followed an identical trial protocol.

The infusion of oxytocin in physiological saline or physiological saline alone was controlled by an Ivac infusion pump, with an initial infusion rate set to provide $2 \mathrm{mU}$ oxytocin/min in the treatment arm of the study. If uterine activity was not judged to be excessive

TABLE I-Characteristics of primiparous women with epidurals

\begin{tabular}{lcc}
\hline & $\begin{array}{c}\text { Study group } \\
(\mathrm{n}=108)\end{array}$ & $\begin{array}{c}\text { Control group } \\
(\mathrm{n}=118)\end{array}$ \\
\hline $\begin{array}{l}\text { Mean (SE) age (years) } \\
\text { Range }\end{array}$ & $24 \cdot 0(0 \cdot 46)$ & $24 \cdot 8(0 \cdot 51)$ \\
$\begin{array}{l}\text { Mean (SE) height (cm) } \\
\text { Range }\end{array}$ & $16-37$ & $17-40$ \\
No given vaginal prostaglandins to & $150-182$ & $162 \cdot 0(0 \cdot 58)$ \\
induce labour & 9 & $145-178$ \\
& & 16 \\
\hline
\end{tabular}

TABLE II -Characteristics of labour in primiparous women with epidurals. Figures are means (SE) except where stated otherwise

\begin{tabular}{|c|c|c|c|c|}
\hline & $\begin{array}{l}\text { Study group } \\
(\mathrm{n}=108)\end{array}$ & $\begin{array}{l}\text { Control group } \\
(n=118)\end{array}$ & $\begin{array}{l}95 \% \text { Confidence } \\
\text { interval for } \\
\text { difference } \\
\text { in means }\end{array}$ & $\mathrm{p}$ Value \\
\hline $\begin{array}{l}\text { Duration of first stage }(\mathrm{h}) \\
\text { Range }\end{array}$ & $\begin{array}{l}8 \cdot 3(0 \cdot 26) \\
3 \text { to } 16\end{array}$ & $\begin{array}{l}9 \cdot 0(0 \cdot 29) \\
4 \text { to } 19\end{array}$ & -0.08 to 1.51 & $0 \cdot 08^{\star}$ \\
\hline Station of fetal head at onset of second & & & & \\
\hline $\begin{array}{l}\text { stage (cm below ischial spine) } \\
\text { Range }\end{array}$ & $\begin{array}{l}0 \cdot 6(0 \cdot 08) \\
-2 \text { to } 3\end{array}$ & $\begin{array}{l}0 \cdot 6(0 \cdot 09) \\
-2 \text { to } 3\end{array}$ & -0.18 to 0.32 & $0 \cdot 5^{\star}$ \\
\hline $\begin{array}{l}\text { Duration of second stage (min) } \\
\text { Range }\end{array}$ & $\begin{array}{l}134(5 \cdot 2) \\
21 \text { to } 286\end{array}$ & $\begin{array}{l}151(4 \cdot 6) \\
20 \text { to } 270\end{array}$ & $3 \cdot 8$ to $31 \cdot 4$ & $0 \cdot 01^{\star}$ \\
\hline $\begin{array}{l}\text { Interval between onset of pushing and delivery } \\
\text { (min) } \\
\text { Range }\end{array}$ & $\begin{array}{l}68(3 \cdot 6) \\
10 \text { to } 179\end{array}$ & $\begin{array}{l}81(3 \cdot 3) \\
7 \text { to } 182\end{array}$ & $3 \cdot 1$ to $22 \cdot 4$ & $0 \cdot 009^{\star}$ \\
\hline Mode of delivery (\%): & & & & \\
\hline Spontaneous & $54(50)$ & $47(40)$ & & \\
\hline Total non-rotational forceps/ventouse & $33(31)$ & $56(47)$ & & \\
\hline Total rotational forceps/ventouse & $19(18)$ & $11(9)$ & & $0.03 \dagger$ \\
\hline Caesarean section & $2(2)$ & $4(3 \cdot 3)$ & & \\
\hline $\begin{array}{l}\text { Postpartum blood loss (ml) } \\
\text { Range }\end{array}$ & $\begin{array}{l}333(27 \cdot 5) \\
50 \text { to } 1800\end{array}$ & $\begin{array}{l}352(16 \cdot 8) \\
50 \text { to } 1000\end{array}$ & -1 to 49 & $0 \cdot 05^{\star}$ \\
\hline No with postpartum haemorrhage & 17 & 24 & & $0 \cdot 4 \dagger$ \\
\hline No with episiotomy or second degree tear (\%) & $71(66)$ & $93(79)$ & & $0.04 \dagger$ \\
\hline
\end{tabular}

TABLE III - Rate of spontaneous delivery in relation to position of occiput at onset of second stage

\begin{tabular}{|c|c|c|c|}
\hline & $\begin{array}{l}\text { Study group } \\
(\mathrm{n}=108)\end{array}$ & $\begin{array}{l}\text { Control group } \\
\quad(n=118)\end{array}$ & p Value* \\
\hline No with fetal occiput anterior at full dilatation & 57 & 70 & \\
\hline Spontaneous delivery $(\%)$ & $36(63)$ & $30(43)$ & 0.03 \\
\hline No with fetal occiput transverse at full dilatation & 17 & 20 & \\
\hline Spontaneous delivery $(\%)$ & $4(24)$ & $8(40)$ & $0 \cdot 4$ \\
\hline No with fetal occiput posterior at full dilatation & 21 & 17 & \\
\hline Spontaneous delivery $(\%)$ & $7(33)$ & $4(24)$ & $0 \cdot 7$ \\
\hline No with position of fetal occiput at full dilatation unknown & 13 & 11 & \\
\hline Spontaneous delivery (\%) & $7(54)$ & $5(45)$ & $0 \cdot 8$ \\
\hline
\end{tabular}

$\chi^{2}$ Test. on clinical grounds by the attending midwife the rate of the drip was doubled every 20 minutes to a maximum rate of $16 \mathrm{mU} / \mathrm{min}$. If there was evidence of an excessive uterine activity (less than one minute of uterine relaxation between contractions or evidence of fetal distress as judged by the fetal heart tracing) the infusion rate was reduced or stopped depending on the circumstances. Intrauterine pressure measurement was not undertaken as it was thought that this could have given the attending staff an indication of the contents of the infusion.

Expulsive efforts by the mother were encouraged once the fetal head became visible (at the perineum) or after one hour had elapsed from the diagnosis of full dilatation. If the woman had the desire to push but the fetal head was not visible then one second stage epidural top up was given. After one hour of maternal expulsive efforts forceps were applied by the attending doctor unless delivery was imminent. All patients were given an intramuscular injection of an oxytocic with delivery of the anterior fetal shoulder. If we suspected fetal distress or inadequate epidural analgesia the women were not entered into the study.

The outcome of labour was assessed for the length of the first and second stages of labour, the level of the presenting part at the onset of the second stage, fetal birth weight, Apgar scores, umbilical artery $\mathrm{pH}$, mode of delivery, episiotomy rate, and the volume of postpartum blood loss. The differences in outcomes between the two groups were assessed statistically by using Student's $t$ test, and proportions were compared with $\chi^{2}$ test. As the blood loss data were logarithmically normally distributed they were logarithmically transformed before analysis.

\section{Results}

Two hundred and twenty six women were entered into the study (160 in Sheffield and 66 in London). One hundred and eight were allocated to receive oxytocin and 118 to receive placebo. All women who received an infusion of oxytocin or placebo were included in the analysis. The two groups were well matched for age and height (table I).

The duration of the first stage of labour and the station of the fetal head at the onset of the second stage were similar in the two groups, but treated patients had a shorter second stage $(\mathrm{p}=0.01)$ and a reduction in the interval between the onset of pushing and delivery $(p=0.009)$ (table II). There were more spontaneous deliveries in the treatment group (50\% v 40\%), which was predominantly due to a reduction in the rate of non-rotational forceps or ventouse deliveries $(47 \%$ to $31 \%, p=0 \cdot 03$, table II); the scale of the reduction was the same in London and Sheffield. There was no reduction in the number of patients who required Kielland's rotational forceps or ventouse delivery for persistent malposition of the occiput in the oxytocin group. Similarly, it can be seen from table III that whereas oxytocin infusion was associated with an increase in the rate of spontaneous delivery when the fetal occiput was in an anterior position at the beginning of the second stage $(63 \% v 43 \%, p=0.03)$ no such benefit was seen if the occiput was in the transverse or posterior position at this time. Such malposition was associated with spontaneous delivery rates of only $11 / 38(30 \%)$ and $12 / 37(32 \%)$ in the treatment and placebo groups, respectively.

There were no significant differences between the two groups in terms of the volume of postpartum blood loss or the incidence of postpartum haemorrhage (table II). Fewer patients required episiotomies or sustained second degree perineal tears in the treatment group $(66 \% v 79 \%, p=0.04$, table II). No differences were seen between treatment and control groups in terms of 
TABLE IV-Fetal outcome in terms of birth weight, umbilical artery $p H$ at delivery, Apgar scores, and neonatal morbidity. Figures are means $(S E)$ except where stated otherwise

\begin{tabular}{|c|c|c|c|c|}
\hline & $\begin{array}{l}\text { Study group } \\
(\mathrm{n}=108)\end{array}$ & $\begin{array}{l}\text { Control group } \\
\quad(n=118)\end{array}$ & $\begin{array}{l}95 \% \text { Confidence } \\
\text { interval for } \\
\text { difference } \\
\text { in means }\end{array}$ & p Value \\
\hline $\begin{array}{l}\text { Birth weight }(\mathrm{g}) \\
\text { Range }\end{array}$ & $\begin{array}{l}3450(40) \\
2680-4830\end{array}$ & $\begin{array}{l}3395(38) \\
2370-4218\end{array}$ & 164 to 54 & $0 \cdot 3$ \\
\hline \multicolumn{5}{|l|}{ Apgar scores: } \\
\hline $\begin{array}{l}\text { At } 1 \text { minute } \\
\text { Range }\end{array}$ & $\begin{array}{l}8 \cdot 1(0 \cdot 14) \\
2-10\end{array}$ & $\begin{array}{l}8 \cdot 1(0 \cdot 13) \\
2-10\end{array}$ & -0.31 to 0.45 & 0.45 \\
\hline $\begin{array}{l}\text { At } 5 \text { minutes } \\
\text { Range }\end{array}$ & $\begin{array}{l}9 \cdot 3(0 \cdot 05) \\
7-10\end{array}$ & $\begin{array}{l}9 \cdot 3(0 \cdot 05) \\
7-10\end{array}$ & -0.17 to 0.14 & 0.9 \\
\hline No of cases of neonatal jaundice & 2 & 5 & & \\
\hline $\begin{array}{l}\text { No of babies requiring admission to special care } \\
\text { baby unit }\end{array}$ & 2 & 4 & & \\
\hline $\begin{array}{l}\text { Umbilical artery } \mathrm{pH} \text { at delivery }{ }_{\text {Range }} \\
\text { Ren }\end{array}$ & $\begin{array}{l}7 \cdot 25(0 \cdot 007) \\
7 \cdot 06-7 \cdot 37\end{array}$ & $\begin{array}{l}7 \cdot 26(0 \cdot 008) \\
7 \cdot 00-7 \cdot 48\end{array}$ & -0.005 to 0.03 & $0 \cdot 13$ \\
\hline
\end{tabular}

TABLE v-Number of patients given epidural top ups in two hours before full dilatation and number of patients given 0,1 , or 2 top ups during second stage (excluding top ups performed in preparation for operative delivery)

\begin{tabular}{lccc}
\hline & $\begin{array}{c}\text { Study group } \\
(\mathrm{n}=108)\end{array}$ & $\begin{array}{c}\text { Control group } \\
(\mathrm{n}=118)\end{array}$ & $\mathrm{p}$ Value \\
\hline No (\%) given epidural top up within two hours before full & & & \\
dilatation & $85(79)$ & $100(85)$ & $0 \cdot 3$ \\
No (\%) given no top up during second stage & $52(48)$ & $56(47)$ & $0 \cdot 3$ \\
No (\%) given one top up during second stage & $48(44)$ & $58(49)$ & $4(3)$ \\
No (\%) given two top ups during second stage & $8(7)$ & $4(3)$ & \\
\hline
\end{tabular}

$\chi^{2}$ Test.

TABLE VI-Characteristics of saline and oxytocin and saline infusions during second stage of labour, including total dose of oxytocin given, number of women in whom maximum infusion rate was achieved, and number in whom drip rate was reduced because of uterine hypertoxicity or abnormal fetal heart rate

\begin{tabular}{lccc}
\hline & $\begin{array}{c}\text { Study group } \\
(\mathrm{n}=108)\end{array}$ & $\begin{array}{c}\text { Control group } \\
(\mathrm{n}=118)\end{array}$ & $\mathrm{p}$ Value \\
\hline Mean (range) dose oxytocin $(\mathrm{mU})$ & $713(10-3928)$ & & \\
No $(\%)$ in whom maximum infusion rate $(16 \mathrm{mU} / \mathrm{min})$ achieved & $40(37)$ & $63(53)$ & 0.01 \\
No $\%$ in whom drip rate reduced & $52(48)$ & $43(36)$ & 0.09 \\
\hline
\end{tabular}

${ }^{\star} \chi^{2}$ Test.

birth weight, umbilical artery $\mathrm{pH}$, Apgar scores, or neonatal morbidity (table IV), and the incidence of fetal distress in the second stage of labour (diagnosed on the basis of abnormalities in the fetal heart rate) was identical (6\%). The management of the epidurals seemed similar in the two groups in that the same volume $(10 \mathrm{ml})$ and concentration $(0.375 \%)$ of local anaesthetic was used in most cases and similar proportions of women had epidural top ups just before and during the second stage of labour (table $\mathrm{V}$ ).

The oxytocin and placebo infusions were managed differently in that the maximum infusion rate of $16 \mathrm{mU}$ oxytocin/min or placebo equivalent was achieved in a smaller proportion of patients receiving oxytocin, but dose reduction was implemented in a high proportion of both the treatment and placebo groups (table VI). Women who ultimately required a rotational forceps delivery received a higher mean maximum dose rate and a higher mean total dose of oxytocin than those having non-rotational forceps or spontaneous deliveries $(14 v 11 v 7 \mathrm{mU} / \mathrm{min}$ and $1565 v 954 v$ $395 \mathrm{mU}$ oxytocin respectively).

\section{Discussion}

Several factors may contribute towards an increased requirement for operative vaginal delivery in association with epidural analgesia. Women are less likely to experience the strong urge to bear down with contractions during the second stage of labour and the maternal expulsive efforts are often visibly less than normal. There may also be an element of selection bias working against the epidural as labour associated with malposition of the occiput is generally held to be less efficient and more painful than when the fetal occiput is anterior, and such patients may be more likely to seek the effective analgesia that an epidural can produce. To a certain extent this may explain why the spontaneous delivery rate associated with the use of epidurals increases as the epidural rate rises $^{14}$ as a higher proportion of low risk patients will be included with each increment in the epidural rate.

The high incidence of malposition of the occiput may be due to laxity of the pelvic floor musculature resulting from the anaesthetic nerve block.' Under these circumstances the fetal occiput may not be directed anteriorly by the levator ani as usually happens when the vertex descends, and persistent malposition of the occiput may result. Also an epidural may reduce uterine activity through suppression of oxytocin release, though not all authors have been able to confirm the existence of the Ferguson reflex in the human ${ }^{1516}$ nor that it is abolished by epidural analgesia. ${ }^{8}$

Our results suggest that giving oxytocin to primiparas with epidurals during the second stage of labour may result in a shortening of the second stage and a useful improvement in the rate of spontaneous delivery when the fetal occiput is anterior. (The reduced requirement for episiotomy is a direct consequence of the reduction in operative delivery rate.) If these effects are mediated through an increase in uterine activity and greater expulsive forces during the second stage then it is interesting that oxytocin did not alter the outcome in those cases in which there was malposition of the occiput. This observation is compatible with the findings of the study by Goodfellow and Studd, in which a small number of women already receiving epidural analgesia and oxytocin augmentation of the first stage of labour were allocated to receive either the same or a higher dose of oxytocin during the second stage. The higher dose regimen was associated with a lower rate of non-rotational forceps delivery but the same rate of rotational forceps delivery. ${ }^{17}$ Possibly poor pelvic floor tone induced by the anaesthetic is indeed responsible for the increased incidence of malposition and this problem cannot be corrected simply by increasing uterine activity. A higher dose of oxytocin might have yielded a better outcome in these cases, but in fact women ultimately delivered by Kielland's forceps received more oxytocin than any other group. Furthermore, in view of the potential danger to the fetus of high doses of oxytocin ${ }^{18}$ we would be reluctant to move to higher infusion rates unless there was direct evidence of uterine inertia as provided by intrauterine pressure measurement. Within the dose range of this study $(2-16 \mathrm{mU} / \mathrm{min})$ no adverse maternal or fetal effects were observed.

We are grateful to the midwifery and pharmacy staff of Northern General, Nether Edge, and Queen Charlotte's Hospitals for their help and Fiona Longley for secretarial help. This work was supported by grants from Birthright and the Royal College of Obstetricians.

1 Hoult IJ, MacLennan AH, Carrie LES. Lumbar epidural analgesia in labour: relation to fetal malposition and instrumental delivery. Br Med $\mathcal{f} 1977 ;$ 14-6.

2 Studd JWW, Selwyn Crawford J, Duignan NM, Rowbotham CJF, Hughes $\mathrm{AD}$. The effect of lumbar epidural analgesia on the rate of cervical dilatation and the out-come of labour of spontaneous onset. $\mathrm{Br} \mathcal{F}$ Obstet Gynaecol 1980;87:1015-21.

3 Philips KC, Thomas SA. Second stage of labour with or without extradural analgesia. Anaesthesia 1983;38:972-6.

4 McQueen J, Mylrea L. Lumbar epidural analgesia in labour. $\mathrm{Br}$ Med $\mathcal{J}$ 1977; i:640-1.

5 Maresh $\mathrm{M}$, Choong $\mathrm{KH}$, Beard RW. Delayed pushing with lumbar epidural analgesia in labour. Brf Obstet Gynaecol 1983;90:623-7.

6 Buxton EJ, Redman CWE, Obhrai M. Delayed pushing with lumbar epidura in labour - does it increase the incidence of spontaneous delivery? fournal of Obstetrics and Gynaecology 1988;8:258-61.

7 Dawood MY, Raghavan KC, Peciasc C, Fuchs F. Oxytocin in human pregnancy and parturition. Obstet Gynecol 1978;51:138-43.

8 Vasicka A, Kumaresan P, Han GS, Kumaresan M. Plasma oxytocin initiation

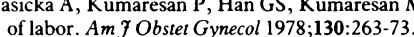

9 Goodfellow CF, Hull MGR, Swaab DF, Dogterom S, Buijs RM. Oxytocin deficiency at delivery with epidural analgesia. Br $f$ Obstet Gynaecol 1983;90:214-6. 
10 Leake RD, Weitzman RE, Glatz TH, Fisher DA. Plasma oxytocin concentrations in men, nonpregnant, and pregnant women before and during spontaneous labor. F Clin Endocrinol Metab 1981;53:730-3.

11 Ferguson JKW. A study of the motility of intact uterus at term. Surg Gynecol Obstet 1941;73:359-66.

12 Debackere M, Peeters G, Tuyttens N. Reflex release of an oxytocic hormone by stimulation of genital organs in male and female sheep studied by a crossby stimulation of genital organs in male and female

13 Bates RG, Hell CW, Duncan A, Edmonds DK. Uterine activity in the second stage of labour and the effect of epidural analgesia. Br 7 Obstet Gynaecol stage of labour and

14 Doughty A. Selective epidural analgesia and the forceps rate. $\mathrm{Br} f$ Anaesth 1969;41:1058-62
15 Sellers SM, Hodgson HG, Mountford LA, Mitchell MD, Anderson ABM, Turnbull AC. Is oxytocin involved in parturition? $\mathrm{Br} \mathcal{F}$ Obstet Gynaecol 1981;88:725-9.

16 De Geest K, Thiery M, Piron Possuyt G, Vanden Driessche R. Plasma oxytocin in human pregnancy and parturition. $\mathcal{F}$ Perinat Med 1985;13:3-13. 17 Goodfellow CF, Studd C. The reduction of forceps in primigravidae with epidural analgesia - a controlled trial. Br f Clin Pract 1979;33:287-8.

18 Liston WA, Campbell AJ. Dangers of oxytocin induced labour to fetuses. BrMed f 1974; iii:606-7.

(Accepted 10 October 1989)

\title{
Hypernatraemic dehydration in patients in a large hospital for the mentally handicapped
}

\author{
N J Macdonald, K N McConnell, M R Stephen, M G Dunnigan
}

\begin{abstract}
Objective-To determine the prevalence of hypernatraemic dehydration and to assess the hydration and nutritional state of patients in a large hospital for the mentally and physically handicapped; also to assess the efficacy of an intervention programme to reduce the prevalence of hypernatraemic dehydration in the hospital.

Design-Prospective study of patients admitted with hypernatraemic dehydration from a large hospital for mentally and physically handicapped patients (hospital A) to a district general hospital between 1986 and 1988. In 1986 the hydration and nutritional state of a random sample of patients from hospital A was compared with a random sample of patients from a small hospital for the physically and mentally handicapped (hospital B) and with control groups from the community. The hydration of the patients from hospital $A$ examined in 1986 was reassessed in 1988 .
\end{abstract}

Patients - 12 Patients were admitted from hospital A to the district general hospital during 1986-8 (seven women, five men; age range 29-82). In 1986, 72 patients were randomly selected for the assessment of hydration and nutritional state from hospital A, 33 who required help with feeding and 39 who could feed independently. Fifty patients were similarly selected from hospital $B$, half of them requiring help with feeding. In 1988 the hydration state of 60 of the 72 patients from hospital was reassessed. Control values were taken from two published studies.

Interventions - In 1987 nursing staff in hospital A were asked to provide between 2.5 and 3.0 litres of fluid daily for all patients. The use of hypertonic enemas was discontinued, and the ratio of staff to patients was increased.

Main outcome measures-Serum concentrations of urea and electrolytes (hydration) and body mass index (nutritional state).

Results - Of the 10 patients admitted with hypernatraemic dehydration from hospital $A$ to the district general hospital in 1986, four died of intercurrent infection. No patients were admitted from hospital $B$ with hypernatraemic dehydration during the same time. In 1986 the hydration and nutritional state of patients in hospital $A$ were inferior to those in patients from hospital $B$ and control subjects from the community (serum urea concentrations were $6 \cdot 1$ (SD 1.8$) \mathrm{mmol} / \mathrm{l} v 5.5(1.9)$ and $5.6(0.4) \mathrm{mmol} / \mathrm{l}$, respectively) $50 \%(36 / 72)$ of patients in hospital $A$ had a body mass index $\leqslant 20$ compared with $34 \%$ (17/ $50)$ of patients from hospital $B$ and $12 \%(1141 / 9434)$ of control subjects). After the initiation of the preventive programme only one patient was admitted with hypernatraemic dehydration in each of the years 1987 and 1988. The mean serum urea concentration of the 60 patients who were reassessed in 1988 fell significantly between 1986 and 1988 from $6 \cdot 1($ SD $1 \cdot 8) \mathrm{mmol} / \mathrm{l}$ to $5 \cdot 7(2 \cdot 1) \mathrm{mmol} / \mathrm{l}$, the value in a control group matched for age and sex.

Conclusions-Hypernatraemic dehydration, subclinical underhydration, and undernutrition were common in a large hospital for the mentally and physically handicapped. The problem of hypernatraemic dehydration was successfully dealt with by the hospital management team. Similar problems may be encountered in hospitals for patients who are mentally and physically handicapped and mentally ill, including psychogeriatric units.

\section{Introduction}

Hypernatraemic dehydration occurs when the loss of free water from the kidney, gastrointestinal tract, skin, and mucous membranes exceeds the intake of water. ${ }^{1}$ Hypernatraemia (usually defined as a serum sodium concentration greater than $150 \mathrm{mmol} / \mathrm{l}$ ) has a mortality approaching $60 \%$ in adults and contributes to the morbidity and mortality of the underlying disease. ${ }^{2}$ Patients whose response to thirst is blunted or whose access to fluids is limited are particularly at risk of hypernatraemic dehydration. This includes infants ${ }^{3}$ and confused or demented elderly people. ${ }^{45}$

People who are mentally handicapped, mentally ill, and physically handicapped might also be expected to be at risk of hypernatraemic dehydration. There are reports of this condition in individual psychotic patients $^{6}$ and in the rare disorder of hypodipsic hypernatraemia associated with various congenital or acquired brain diseases. ${ }^{7}$ Hypernatraemic dehydration resulting from predominantly environmental factors in psychiatric institutions has not been previously described.

In January 1986 three patients with hypernatraemic dehydration were admitted to the medical division of this hospital from a large hospital for the mentally and physically handicapped (hospital A). Since then all admissions from hospital A to this hospital have been monitored to detect further cases of hypernatraemic dehydration. The reasons for its occurrence have been investigated and effective preventive measures implemented.

\section{Patients and methods}

In March 1986 a venous blood sample was taken from 72 mentally handicapped patients from 14 wards in hospital A. Serum concentrations of electrolytes, 